\title{
PEMBELAJARAN KONTEKSTUAL IPA MELALUI OUTDOOR LEARNING DI SD ALAM AR-RIDHO SEMARANG
}

\author{
Nunung Dwi Setiyorini \\ Politeknik Negeri Semarang \\ Email: setyorinidwi7@gmail.com
}

\begin{abstract}
Abstrak
Penelitian ini bertujuan untuk mendeskripsikan dan menganalisis pembelajaran kontekstual IPA di SD Alam Ar-Ridho Semarang, mendeskripsikan dan menganalisis Outdoor Learning di SD Alam Ar-Ridho Semarang, dan mendeskripsikan dan menganalisis pembelajaran kontekstual IPA melalui Outdoor Learning di SD Alam ArRidho Semarang. Penelitian ini menggunakan pendekatan kualitatif dengan rancangan studi kasus. Pengumpulan data dilakukan dengan teknik wawancara, observasi, dan dokumentasi. Teknik analisis data meliputi reduksi data, penyajian data, dan penarikan kesimpulan, pengecekan keabsahan temuan dilakukan dengan cara perpanjang keikutsertaan peneliti dan triangulasi. Informan penelitian yaitu kepala sekolah, para pendidik dan siswa. Hasil penelitian menunjukkan bahwa : (1) pembelajaran IPA dengan menggunakan model pembelajaran kontekstual dapat meningkatkan pemahaman konsep siswa. Karena dalam penerapan model pembelajaran kontekstual, guru menghubungkan antara pengetahuan yang diperoleh siswa dengan pengetahuan yang telah dimiliki siswa sebelumnya dan guru juga menghubungkan materi dengan dunia nyata siswa yaitu dengan membawa benda-benda yang sering mereka temui untuk dijadikan media pembelajaran sehingga dapat membantu memudahkan siswa dalam mengkonsepkan materi IPA; (2) pendekatan Outdoor Learning merupakan salah satu alternatif pembelajaran IPA yang sesuai dengan semangat belajar IPA yaitu cara mencari tahu dan mengembangkan ketrampilan ilmiah siswa. Selain itu melalui pendekatan Outdoor Learning berbagai potensi siswa memiliki peluang untuk berkembang lebih optimal karena ada interaksi yang nyata antara siswa dengan dunia nyata; dan (3) pembelajaran kontekstual dalam pembelajaran IPA tidak hanya dilaksanakan di dalam kelas (Indoor) saja, tetapi lebih banyak dilakukan di luar kelas (Outdoor). Sehingga siswa lebih mudah memahami materi yang telah disampaikan guru, siswa lebih cepat menangkap makna pembelajaran IPA, siswa mengerjakan pekerjaan-pekerjaan yang berarti, siswa mampu berkerja sama dalam kelompok, dan siswa lebih kritis dan kreatif dalam memberitangapan dalam pembelajaran IPA.
\end{abstract}

Kata Kunci: Model Pembelajaran Kontekstual, IPA, Outdoor Learning

\section{A. PENDAhuluAN}

Pendidikan dasar merupakan fondasi dasar dari semua jenjang sekolah selanjutnya. Diungkapkan Muhammad $\mathrm{Ali}^{1}{ }^{1}$ bahwa tujuan penyelenggaraan pendidikan dasar adalah menyiapkan siswa agar menjadi manusia yang bermoral, menjadi warga negara yang mampu melaksanakan kewajiban-kewajibannya, dan menjadi orang dewasa yang mampu memperoleh pekerjaan. Secara operasional, tujuan pokok pendidikan dasar adalah membantu siswa dalam mengembangkan kemampuan intelektual dan mentalnya, proses perkembangan sebagai individu yang

\footnotetext{
${ }^{1}$ Mohammad Ali, Pendidikan untuk Pengembangan Nasional, (Bandung: Imperial Bhakti Utama, 2009), hlm. 290.

Vol. 1 No. 1 / April 2018

Al - Mudarris homepage: http://e-journal.staima-alhikam.ac.id/index.php/al-mudarris/
} 
mandiri, proses perkembangan sebagai makhluk sosial, belajar hidup menyesuaikan diri dengan berbagai perubahan, dan meningkatkan kreativitas. ${ }^{2}$

Berdasarkan pengamatan di lapangan, masih banyak ditemukan pelaksanaan pembelajaran yang masih kurang variatif khususnya pada pembelajaran IPA. Proses pembelajaran IPA memiliki kecenderungan pada metode atau model konvensional, serta proses pembelajaran IPA tidak memperhatikan tingkat pemahaman siswa terhadap informasi yang disampaikan. Karena proses pembelajaran IPA di sekolah dasar hanya menekankan proses pemahaman fenomena alam saja, yakni proses deduktif. Hal ini memang berhasil membuat siswa kritis analitis, tetapi efek sampingnya membunuh kreativitas siswa dalam menyisir fakta-fakta dan fenomena rumit untuk menghasilkan konsep hipotesis atau model teori yang sederhana. ${ }^{3}$

Pembelajaran IPA merupakan proses memberikan pengalaman kepada siswa tentang fenomena atau gejala alam. Maka dari itu, pembelajaran IPA bisa dilakukan di luar kelas (Outdoor Learning) sehingga siswa bisa langsung memecahkan masalah pembelajaran IPA dengan memanfaatkan lingkungan yang ada di sekitar sekolah. Kegiatan pembelajaran memang tidak selamanya harus dilaksanakan di kelas, terkadang juga harus di tempat sumber dimana informasi ini secara langsung dapat diperoleh.

Sekolah Dasar Alam Ar-Ridho Semarang sebagai salah satu sekolah formal yang menerapkan model pembelajaran kontekstual melalui pendekatan Outdoor Learning dalam proses pembelajaran. Konsep pendidikan yang dikembangkan oleh Sekolah Dasar Alam Ar-Ridho core value. Adapun konsep yang dikembangkan adalah akhlak dan leadership, logika dan akademika, lingkungan dan konservasi, bakat dan skill, seni dan kreatifitas serta pembelajaran berbasis penanaman nilai lingkungan (ekologi) yang memanfaatkan alam sebagai sumber belajar siswa, Dalam proses pembelajaran guru selalu melibatkan alam sebagai media dalam memecakan masalah.

Pendekatan Outdoor Learning adalah pendidikan yang berlangsung di luar kelas yang melibatkan pengalaman yang membutuhkan partisipasi siswa untuk mengikuti tantangan petualangan yang menjadi dasar dari aktivitas luar kelas seperti heking, mendaki gunung, camping dan lain-lain. ${ }^{4}$ Sedangkan Archibald Callaway mendefinisikan Outdoor Learning adalah sebagai suatu bentuk kegiatan belajar yang berlangsung di luar kelas ${ }^{5}$

Masalah yang timbul di SD Alam Ar-Ridho adalah guru ingin menanamkan bahwa lingkungan adalah tempat untuk belajar, guru ingin menanamkan konsep peduli lingkungan kepada semua siswa, guru ingin memperkenalkan atau menunjukkan bahwa lingkungan sangat penting bagi manusia. Maka dari itu, siswa harus selalu berbuat baik terhadap lingkungan yang ada disekitarnya. Agar semua siswa tidak lagi melakukan tindakan-tindakan yang menyebabkan menurunnya kualitas lingkungan hidup, dan dengan penuh kesadaran mereka berhenti melakukan

\footnotetext{
${ }^{2}$ Andi Prastowo, Pengembangan Bahan Ajar Tematik, (Jogjakarta: DIVA Press, 2013), hlm. 13.

${ }^{3}$ Budi Susetyo, Pengembangan Model Pembelajaran Fisika Berbasis Empat Pilar Pendidikan Melalui Outdoor-Inquiry untuk Menumbuhkan Keberhasilan Bekerja Ilmiah, Tesis, (Semarang: Unnes, 2008), hlm. 1.

${ }^{4}$ Husamah, Pembelajaran Luar Kelas Outdoor Learning, (Jakarta: Prestasi Pustaka, 2013), hlm. 20.

${ }^{5}$ Saleh Marzuki, Pendidikan Non Formal: Dimensi dalam Keaksaraan Fungsional, Pelatihan dan Andragogi, (Bandung: Remaja Rosdakarya, 2012), hlm. 99.

Vol. 1 No. 1 / April 2018

$\mathrm{Al}$ - Mudarris homepage: http://e-journal.staima-alhikam.ac.id/index.php/al-mudarris/
} 
perbuatan itu, serta berbalik melakukan kegiatan-kegiatan yang dapat melestarikan lingkungan sehingga ekosistem aman dan terjaga kelestariannya.

Alasan utama peneliti mengkaji pembelajaran kontekstual IPA melalui Outdoor Learning di SD Alam Ar-Ridho Semarang adalah untuk mendeskripsikan dan menganalisis pembelajaran kontekstual IPA, mendeskripsikan dan menganalisis Outdoor Learning dan mendeskripsikan dan menganalisis pembelajaran kontekstual IPA melalui Outdoor Learning.

Penggabungan antara model pembelajaran kontekstual dengan pendekatan Outdoor Learning merupakan satu jalan bagaimana guru dapat meningkatkan kapasitas belajar siswa. Karena model pembelajaran kontekstual menekankan pada konsep belajar yang membantu guru mengaitkan antara materi yang diajarkannya dengan situasi dunia nyata siswa dan mendorong siswa membuat hubungan antara pengetahuan yang dimilikinya dengan penerapannya dalam kehidupan mereka sebagai anggota keluarga dan masyarakat. Sedangkan pendekatan Outdoor Learning merupakan suatu kegiatan di luar kelas yang menjadikan pembelajaran di luar kelas menarik dan menyenangkan, bisa dilakukan dimanapun dengan menekankan pada proses belajar berdasarkan fakta nyata, yang materi pembelajarannya secara langsung dialami melalui kegiatan pembelajaran secara langsung dengan harapan siswa dapat lebih membangun makna atau kesan dalam memori atau ingatanya. Sehingga siswa dapat belajar secara lebih mendalam melalui objek-objek yang dihadapi dari pada jika belajar di dalam kelas (Indoor Learning) yang memiliki banyak keterbatasan.

Berdasarkan uraian di atas, maka peneliti tertarik untuk mengkaji lebih dalam dengan mengangkat judul "Pembelajaran Kontekstual IPA Melalui Outdoor Learningdi SD Alam Ar-Ridho Semarang.

\section{B. KAJIAN PUSTAKA}

\section{Pembelajaran Kontekstual}

Pembelajaran kontekstual atau contextual teaching learningmerupakan suatu konsepsi yang membantu guru mengaitkan konten mata pelajaran dengan situasi dunia nyata dan memotivasi siswa membuat hubungan antara pengetahuan dan penerapannya dalam kehidupan mereka sebagai anggota keluarga, warga negara dan tenaga kerja. ${ }^{6}$ Pembelajaran kontekstual medorong siswa membuat hubungan antara pengetahuan yang dimilikinya dan penerapannya dalam kehidupan mereka sendiri-sendiri. Dimana pengetahuan dan keterampilan siswa diperoleh dari usaha siswa mengkonstruksi sendiri pengetahuan dan keterampilan baru ketika ia belajar.

Pembelajaran kontekstual menekankan pada berpikir tingkat lebih tinggi, transfer pengetahuan lintas disiplin, serta pengumpulan, penganalisisan dan pensintesisan informasi dan data dari berbagai sumber dan pandangan. Pembelajaran kontekstual mengamsumsikan bahwa secara natural pikiran mancari makna konteks sesuai dengan situasi nyata lingkungan seseorang, dan itu dapat terjadi melalui pencarian hubungan yang masuk akal dan bermanfaat. Pemanduan materi pelajaran dengan konteks keseharian siswa di dalam pembelajaran kontekstual akan menghasilkan dasar-dasar pengetahuan yang mendalam dimana siswa kaya akan pemahaman masalah dan cara untuk

\footnotetext{
${ }^{6}$ Trianto, Mendesain Model Pembelajaran Inovatif-Progresif, (Jakarta: Kencana, 2009), hlm.
} 104.

Vol. 1 No. 1 / April 2018

$\mathrm{Al}$ - Mudarris homepage: http://e-journal.staima-alhikam.ac.id/index.php/al-mudarris/ 
menyelesaikannya. Siswa mampu mencari independent penggunakan pengetahuannya untuk menyelesaikan masalah-masalah baru dan belum pernah dihadapi, serta memiliki tanggung jawab yang lebih terhadap belajarnya seiring dengan peningkatan pengalaman dan pengetahuan mereka.

2. IPA

Carin dan Sund mendefinisikan IPA sebagai pengetahuan yang sistematis dan tersusun secara teratur, berlaku umum (universal), dan berupa kumpulan data hasil observasi dan eksperimen. Merujuk pada definisi Carin dan Sund tersebut maka IPA memiliki empat unsur utama, yaitu: ${ }^{7}$

1) Sikap. IPA memunculkan rasa ingin tahu tentang benda, fenomena alam, makhluk hidup, serta hubungan sebab akibat. Persoalan IPA dapat dipecahkan dengan menggunakan prosedur yang bersifat open ended.

2) Proses. Proses pemecahan masalah pada IPA memungkinkan adanya prosedur yang runtut dan sistematis melalui metode ilmiah. Metode ilmiah meliputi penyusunan hipotesis, perencanaan eksperimen atau percobaan, evaluasi, pengukuran, dan penarikan kesimpulan.

3) Produk. IPA menghasilkan produk berupa fakta, prinsip, teori dan hukum.

4) Aplikasi. Penerapan metode ilmiah dan konsep IPA dalam kehidupan seharihari.

IPA berupaya membangkitkan minat siswa agar dapat meningkatkan kecerdasan dan pemahamannya tentang alam seisinya yang penuh rahasia yang tak habis-habisnya. Khususnya untuk IPA di SD/MI hendaknya membuka kesempatan untuk memupuk rasa ingin tahu peserta didik secara alamiah.

\section{Outdoor Learning}

Pendekatan Outdoor Learning juga jelas tujuannya yaitu memenuhi kebutuhan sasaran siswa dan menyediakan tentang apa yang mereka perlukan dalam kebutuhan nyata yang dialami siswa sehari-hari. Karena pentingnya pembelajaran secara langsung kepada siswa di bawah ini akan dipaparkan hadits mengenai pentingnya belajar dengan melibatkan alam. Menurut Husamah Outdoor Learning merupakan aktivitas luar sekolah yang berisi kegiatan di luar kelas atau sekolah dan di alam bebas lainnya, seperti: bermain di lingkungan sekolah, taman, perkampungan pertanian/nelayan, berkemah, dan kegiatan yang bersifat kepetualangan, serta pengembangan aspek pengetahuan yang relevan. ${ }^{8}$

Pengajar atau guru bertugas untuk mengarahkan para siswa untuk melakukan aktivitas yang bisa membawa siswa pada perubahan prilaku terhadap lingkungan sekitar. Melalui Outdoor Learning lingkungan di luar sekolah dapat digunakan sebagai sumber belajar. Sehingga siswa akan terhindar dari kebosanan dalam menerima pelajaran di dalam kelas dan siswa akan lebih mudah memahami konsep-konsep materi karena dalam menemui obyek langsung di lapangan.

Outdoor Learning bisa diterapkan pada sekolah dasar, sekolah menengah dan sekolah menengah atas. Berikut manfaat Outdoor Learning.

1) Kegiatan belajar lebih menarik dan tidak membosankan siswa duduk berjamjam, sehingga motivasi belajar siswa akan lebih tinggi.

2) Hakekat belajar akan lebih bermakna sebab siswa dihadapkan dengan situasi dan keadaan yang sebenarnya atau bersifat alami.

\footnotetext{
${ }^{7}$ Asih Widi Wisudawati dan Eka Sulistyowati, Metodologi Pembelajaran IPA, hlm. 24.

${ }^{8}$ Husamah, Pembelajaran Luar Kelas, hlm. 19.
}

Vol. 1 No. 1 / April 2018

$\mathrm{Al}$ - Mudarris homepage: http://e-journal.staima-alhikam.ac.id/index.php/al-mudarris/ 
3) Bahan-bahan yang dapat dipelajari lebih kaya serta lebih faktual sehingga kebenarannya akurat.

4) Kegiatan belajar siswa lebih komprehensif dan lebih aktif sebab dapat dilakukan dengan berbagai cara seperti mengamati, bertanya atau wawancara, membuktikan atau mendemonsrasikan, menguji fakta, dan lainlain.

5) Sumber belajar lebih kaya sebab lingkungan yang dapat dipelajari bisa beraneka ragam seperti lingkungan sosial, lingkungan alam, lingkungan buatan, dan lain-lain.

6) Siswa dapat memahami dan menghayati aspek-aspek kehidupan yang ada di lingkungannya, sehingga dapat membentuk pribadi yang tidak asing dengan kehidupan membentuk sekitarnya, serta dapat memupuk cinta lingkungan. ${ }^{9}$

Proses pembelajaran secara langsung dapat memberikan pengalaman nyata pada siswa, artinya pengajaran itu akan semakin konkrit, sehingga siswa akan terhindar dari kesalahan persepsi dari pembahasan materi pelajaran tertentu.

\section{METODE PENELITIAN}

Penelitian ini menggunakan pendekatan kualitatif, dengan maksud peneliti dapat mendeskripsikan secara jelas dan terperinci, serta mendapat data yang mendalam dari fokus penelitian tentang pembelajaran kontekstual IPA melalui Outdoor Learning di SD Alam Ar-Ridho Semarang. Dengan jenis penelitian studi kasus (Case Study).

Karena dalam peneliti bermaksud ingin mengetahui tentang pembelajaran kontekstual IPA melalui Outdoor Learning di SD Alam Ar-Ridho Semarang. Maka dengan itu, peneliti akan berusaha memaparkan realitas pembelajaran kontekstual IPA melalui Outdoor Learning di SD Alam Ar-Ridho Semarang. Yaitu dengan mendeskripsikan suatu keadaan atau fenomenafenomena apa adanya.Selain itu juga, peneliti mengamati secara langsung terhadap fenomena yang tampak, situasi serta kondisi dari objek penelitian yang informasinya dapat diambil dari berbagai responden dan dokumen-dokumen pendukung lainnya.

Adapun sumber data primer dalam penelitian ini adalah Kepala yayasan, Kepala sekolah, semua guru serta semua siswa-siswi SD Alam Ar-Ridlo Semarang. Data sekunder ini akan diperoleh dari dokumen-dokumen tertulis dan foto-foto. Teknik pengumpulan data dalam penelitian ini adalah observasi, wawancara, dan dokumentasi

Analisis data dalam penelitian ini peneliti menggunakan model interaktif yaitu, proses reduksi data (interpretation, proses penyajian data (Display Data), dan proses menarik kesimpulan (Verivikasi Data). Dalam penelitian ini, yang digunakan dalam mengecek keabsahan data penelitian, yaitu perpanjangan keikutsertaan, dan trianggulasi

\section{TEMUAN DAN PEMBAHASAN}

Hasil penelitian tentang pembelajaran kontekstual IPA di SD Alam ArRidho Semarang yang dilakukan dengan wawancara dan observasi terhadap beberapa responden, yang terdiri dari kepala sekolah SD Alam Ar-Ridho, guru

\footnotetext{
${ }^{9}$ Husamah, Pembelajaran Luar Kelas, hlm. 25.
}

Vol. 1 No. 1 / April 2018

$\mathrm{Al}$ - Mudarris homepage: http://e-journal.staima-alhikam.ac.id/index.php/al-mudarris/ 
IPA dan siswa. Pembelajaran kontekstual IPA di SD Alam Ar-Ridho dalam pembelajaran IPA meliputi: Menjalin hubungan-hubungan yang bermakna dalam pembelajaran IPA, mengerjakan pekerjaan-pekerjaan yang berarti dalam pembelajaran IPA, siswa menemukan sendiri dalam pembelajaran IPA, mengadakan kolaborasi dalam pembelajaran IPA, berpikir kritis dan kreatif dalam pembelajaran IPA, pemodelan dalam pembelajaran IPA, refleksi dalam pembelajaran IPA, dan menggunakan asesmen autentik dalam pembelajaran IPA. Adapun penjelasannya adalah sebagai berikut:

Hasil dari penelitian di SD Alam Ar-Ridho Outdoor Learning meliputi: pertama, lingkungan di dalam sekolah yaitu: kebun sekolah, aqua ponik, area outbound siswa, lapangan, dan rumah panggung. Kedua, lingkungan di luar sekolah yaitu: tracking dan outing. Tempat-tempat tracking yang sering di kunjungi siswa SD Alam Ar-Ridho adalah: hutan, sawah, dan perumahan. Sedangkan tempat-tempat outing yang sering di kunjungi siswa SD Alam ArRidho adalah: museum, kebun binatang, pabrik kertas, pabrik roti, pembangkit listrik, dan pabrik sosro.

Pendekatan Outdoor Learning di SD Alam Ar-Ridho merupakan satu jalan bagaimana sekolah dapat meningkatkan kapasitas belajarsiswa dalam pembelajaran. Siswa dapat belajar lebih mendalam melalui objek-objek yang dihadapi dari pada jikabelajar di dalam kelas (Indoor) yang memiliki banyak keterbatasan. Lebih lanjut, belajar di luar kelas (Outdoor Learning) dapatmenolong siswa untuk mengaplikasikan pengetahuan yang dimiliki. Selain itu, pembelajaran di luarkelas (Outdoor Learning) lebih menantang bagi siswa dan menjembatani antara teori di dalam buku dan kenyataan yang ada di lapangan. Kualitas pembelajaran dalam situasi yang nyata memberikan peningkatan kapasitas pencapaian belajar melalui objek yang dipelajari serta dapat membangun ketrampilan sosialdan personal yang lebih baik. Pembelajaran dengan menggunakan pendekatan Outdoor Learning dapat dilakukan kapanpun sesuai dengan rancangan program yang dibuat oleh guru.

Hasil dari penelitian SD Alam Ar-Ridho Semarang merupakan SD yang telah menerapkan model pembelajaran kontekstual IPA dengan menggunakan pendekatan Outdoor Learning. Model pembelajaran kontekstual merupakan suatu strategi pembelajaran yang menekankan kepada proses keterlibatan siswa secara penuh untuk dapat menemukan materi yang dipelajari dan menghubungkannya dengan situasi kehidupan nyata sehingga mendorong siswa untuk dapat menerapkannya dalam kehidupan mereka. Sedangakan pendekatan Outdoor Learning merupakan suatu kegiatan di luar kelas yang menjadikan pembelajaran di luar kelas menarik dan menyenangkan, bisa dilakukan dimanapun dengan menekankan pada proses belajar berdasarkan fakta nyata, yang materi pembelajarannya secara langsung dialami melalui kegiatan pembelajaran secara langsung dengan harapan siswa dapat lebih membangun makna atau kesan dalam memori atau ingatanya. Adapun hasil dari model pembelajaran kontekstual IPA melalui Outdoor Learning di SD Alam Ar-Ridho Semarang adalah:

a. Pembelajaran Kontekstual IPA Melalui Lingkungan di dalam Sekolah

Pembelajaran kontekstual IPA dengan menggunakan pendekatan Outdoor Learning mengasumsikan bahwa secara natural pikiran mencari makna konteks sesuai dengan situasi nyata lingkungan seseorang melalui

Vol. 1 No. 1 / April 2018

$\mathrm{Al}$ - Mudarris homepage: http://e-journal.staima-alhikam.ac.id/index.php/al-mudarris/ 
pencarian hubungan masuk akal dan bermanfaat. Melalui pemaduan materi yang dipelajari dengan pengalaman keseharian siswa akan menghasilkan dasar-dasar pengetahuan yang mendalam. Siswa akan mampu menggunakan pengetahuannya untuk menyelesaikan masalah-masalah baru dan belum pernah dihadapinya dengan peningkatan pengalaman dan pengetahuannya. Siswa diharapkan dapat membangun pengetahuannya yang akan diterapkan dalam kehidupan sehari-hari dengan memadukan materi pelajaran yang telah diterimanya di sekolah.

Belajar bermakna terjadi melalui refleksi, pemecahan konflik, dialog, penelitian, pengujian hipotesis, pengambilan keputusan, dan dalam prosesnya tingkat pemikiran selalu diperbaharui sehingga menjadi semakin lengkap. Berdasarkan hasil penelitian membuktikan bahwa berhasil atau tidaknya belajar tergantung pada makna dari apa yang dipelajari. Lebih lanjut dinyatakan bahwa pelajaran yang bermakna jika pelajaran tersebut atau masalah yang dipelajari itu riil atau berharga bagi siswa dan sejauh hubungan esensial antara bagian-bagiannya ditegaskan. Sehingga tugas siswa adalah menangkap dan memahami hubungan dalam keseluruhannya.

b. Pembelajaran Kontekstual IPA Melalui Lingkungan di Luar Sekolah

SD Alam Ar-Ridho Semarang mengajak siswanya untuk selalu berpikir kritis dan guru memanfaatkan model pembelajaran kontekstual dengan menggunakan pendekatan Outdoor Learning dalam menagajar IPA. Keterampilan berpikir kritis bukan merupakan suatu keterampilan yang dapat berkembang dengan sendirinya seiring dengan perkembangan fisik manusia. Keterampilan ini harus dilatih melalui pemberian stimulus yang menuntut seseorang untuk berpikir kritis. Sekolah sebagai suatu institusi penyelenggara pendidikan memiliki tanggung jawab untuk membantu siswanya mengembangkan keterampilan berpikir kritis. Keterampilan berpikir kritis merupakan suatu proses intelektual tentang konseptualisasi, penerapan, analisis, sintesis, dan evaluasi secara aktif dan mahir terhadap informasi yang diperoleh dari observasi, pengalaman, refleksi, pemikiran, atau komunikasi sebagai pedoman untuk meyakini dan bertindak. Keterampilan ini ditandai oleh nilai-nilai intelektual yang bersifat universal, yaitu kejelasan, ketepatan, konsistensi, ketelitian, kesesuaian, bukti yang benar, pemikiran yang baik, kedalaman, keluasan, dan keadilan.

\section{E. KESIMPULAN}

Berdasarkan hasil informasi, data, temuan dan pembahasan, maka hasil penelitian tentang Pembelajaran Kontekstual IPA Melalui Outdoor Learning di SD Alam Ar-Ridho Semarang dapat disimpulkan sebagai berikut:

a. Pembelajaran Kontekstual IPA di SD Alam Ar-Ridho Semarang

1) Pembelajaran IPA dengan menggunakan model pembelajaran kontekstual dapat meningkatkan pemahaman konsep siswa.

2) Aktifitas siswa dapat dilihat atau diobservasi selama proses pembelajaran menggunakan model pembelajaran kontekstual dalam pelajaran IPA diantaranya, siswa menjadi lebih aktif, yaitu siswa tidak malu menyampaikan jawaban di depan kelas, tidak malu untuk bertanya, siswa selalu berebut maju dengan mengangkat tangannya, siswa dapat berkomunikasi dengan teman-teman dalam pembelajaran sepertisiswa 
akan secara sadar bergabung dengan kelompoknya tanpa banyak membuang waktu, siswa juga lebih kritis dalam menerima materi, siswa dituntut untuk mengkonsepkan materi pelajaran yang siswa terima.

b. Outdoor Learning di SD Alam Ar-Ridho Semarang

Pendekatan Outdoor Learning merupakan salah satu alternatif pembelajaran IPA yang sesuai dengan semangat belajar IPA yaitu cara mencari tahu dan mengembangkan ketrampilan ilmiah siswa. Selain itu melalui pendekatan Outdoor Learning berbagai potensi siswa memiliki peluang untuk berkembang lebih optimal karena ada interaksi yang nyata antara siswa dengan dunia nyata.

c. Pembelajaran Kontekstual IPA Melalui Outdoor Learning di SD Alam ArRidho Semarang

1) Pembelajaran kontekstual dengan menggunakan pendekatan Outdoor Learning dalam pembelajaran IPA di SD Alam Ar-Ridho Semarang sudah bagus. Hal ini bisa dilihat dari hasil penelitian, bahwa pembelajaran kontekstual di SD Alam Ar-Ridho sudah menerapkan lima poin sistem pembelajaran kontekstual, yaitu menjalin hubunganhubungan yang bermakna (making meaningful connections), mengerjakan pekerjaan-pekerjaan yang berarti (doing significant work), mengadakan kolaborasi (collacorating), berpikir kritis dan kreatif (critical and creative thingking), dan menggunakan asesmen autentik (using authentic).

2) Proses pembelajaran kontekstual dalam pembelajaran IPA tidak hanya dilaksanakan di dalam kelas (Indoor) saja, tetapi lebih banyak dilakukan di luar kelas (Outdoor).

a) Sumber daya manusia di SD Alam Ar-Ridho Semarang sudah baik. Lingkungan di dalam sekolah di manfaatkan guru sebagai lokasi pembelajaran IPA. Adapun lokasi-lokasitersebut adalah kebun sekolah, aqua ponik, area Outbound siswa, lapangan, dan rumah panggung.

b) Lingkungan di luar sekolah juga dijadikan alternatif sebagai lokasi pembelajaran IPA. Adapun lokasi-lokasi tersebut dibagi menjadi dua yaituTracking dan Outing. Lokasi-lokasi Tracking yang biasa dimanfaatkan guru adalah hutan, sawah, dan perumahan. Sedangkan lokasi-kokasi Outing yaitu museum, kebun binatang, pabrik kertas, pabrik roti, dan pabrik sosro.

\section{DAFTAR PUSTAKA}

Ali,Mohammad. Pendidikan untuk Pengembangan Nasional. Bandung: Imperial Bhakti Utama. 2009

Husamah. Pembelajaran Luar Kelas Outdoor Learning. Jakarta: Prestasi Pustaka. 2013

Marzuki, Saleh.. Pendidikan Non Formal: Dimensi dalam Keaksaraan Fungsional, Pelatihan dan Andragogi. Bandung: Remaja Rosdakarya. 2012

Prastowo, Andi. Pengembangan Bahan Ajar Tematik. Jogjakarta: DIVA Press. 2013

Susetyo,Budi. 2008. Pengembangan Model Pembelajaran Fisika Berbasis Empat Pilar

Pendidikan Melalui Outdoor-Inquiry untuk Menumbuhkan Keberhasilan Bekerja Ilmiah, Tesis, Semarang: Unnes,.

Trianto. Mendesain Model Pembelajaran Inovatif-Progresif, Jakarta: Kencana. 2009

Vol. 1 No. 1 / April 2018

$\mathrm{Al}$ - Mudarris homepage: http://e-journal.staima-alhikam.ac.id/index.php/al-mudarris/ 
Widi Wisudawati, Asih dan Eka Sulistyowati.. Metodologi Pembelajaran IPA, Jakarta: Bumi Aksara. 2014 